\title{
Arsenic in marine sediments from French Mediterranean ports: Geochemical partitioning, bioavailability and ecotoxicology
}

\author{
Yannick Mamindy-Pajany ${ }^{\mathrm{a}, *}$, Charlotte Hurel ${ }^{\mathrm{b}}$, Florence Géret ${ }^{\mathrm{b}}$, François Galgani ${ }^{\mathrm{c}}$, \\ Fabienne Battaglia-Brunet ${ }^{\mathrm{d}}$, Nicolas Marmier ${ }^{\mathrm{a}}$, Michèle Roméo ${ }^{\mathrm{a}}$
}

\footnotetext{
a University of Nice Sophia Antipolis, Laboratoire des Ecosystèmes marins côtiers et réponses aux stress (ECOMERS/EA 4228), Faculty of Sciences, Parc Valrose, 06108 Nice Cedex 02, France

${ }^{b}$ University Center Jean-François Champollion, Laboratoire GEODE, Place de Verdun, 81012 Albi, France

c IFREMER Corse, Laboratoire Environnement Ressources PAC/Corse Imm Agostini, ZI Furiani, 20600 Bastia, France

d BRGM Orléans, 3 av. Claude Guillemin, 45060 Orléans Cedex 02, France
}

\author{
*: Corresponding author : Yannick Mamindy-Pajany, Tel.: +33 (0)4 92076370 ; fax: +33 (0)4 92076364 ; \\ email address : yannickpajany@hotmail.com
}

\begin{abstract}
:
This work investigates arsenic mobility, bioavailability and toxicity in marine port sediments using chemical sequential extraction and laboratory toxicity tests. Sediment samples were collected from two different Mediterranean ports, one highly polluted with arsenic and other inorganic and organic pollutants (Estaque port (EST)), and the other one, less polluted, with a low arsenic content (Saint Mandrier port (SM)). Arsenic distribution in the solid phase was studied using a sequential extraction procedure specifically developed for appraising arsenic mobility in sediments. Toxicity assessment was performed on sediment elutriates, solid phases and aqueous arsenic species as single substance using the embryo-toxicity test on oyster larvae (Crassostrea gigas) and the Microtox test with Vibrio fischeri. Toxicity results showed that all sediment samples presented acute and sub-chronic toxic effects on oyster larvae and bacteria, respectively. The Microtox solid phase test allow to discriminate As-contaminated samples from the less contaminated ones, suggesting that toxicity of whole sediment samples is related to arsenic content. Toxicity of dissolved arsenic species as single substance showed that Vibrio fischeri and oyster larvae are most sensitive to $\mathrm{As}(\mathrm{V})$ than $\mathrm{As}(\mathrm{III})$. The distribution coefficient $(\mathrm{Kd})$ of arsenic in sediment samples was estimated using results obtained in chemical sequential extractions. The Kd value is greater in SM $\left(450 \mathrm{~L} \mathrm{~kg}^{-1}\right)$ than in EST $\left(55 \mathrm{~L} \mathrm{~kg}^{-1}\right)$, indicating that arsenic availability is higher for the most toxic sediment sample (Estaque port). This study demonstrates that arsenic speciation play an important role on arsenic mobility and its bioavailability in marine port sediments.
\end{abstract}

Keywords: Arsenic speciation ; Chemical sequential extraction ; Embryo-toxicity test ; Marine sediment ; Microtox toxicity test ; Pollutant bioavailability 


\section{Introduction}

Sediments in estuaries and coastal areas constitute important sinks of contaminants and represent potential sources of pollution to the marine environment. A number of studies carried out in recent years has shown the presence of a wide range of inorganic (As, $\mathrm{Cd}, \mathrm{Cu}$, $\mathrm{Ni}, \mathrm{Pb}, \mathrm{Zn}$ ) and organic contaminants (PAHs, PCBs) in Mediterranean port sediments (Andral et al., 2004; Apitz et al., 2007; Mamindy-Pajany et al., 2010a). Remobilisation of sediment-associated contaminants can occur during natural events (i.e. tidal movement and storms) or anthropogenic activities (i.e. dredging, marine disposal of dredged materials and capping) and increase the bioavailability of pollutants in water column (Eggleton and Thomas, 2004). Due to its high concentration in marine sediments, arsenic can cause acute and chronic toxicity to marine organisms via ingestion of particulate matter (As associated with particles), through membrane-facilitated transport or passive diffusion (As dissolved in water) (Bhattacharya et al., 2007).

Within the framework of dredged sediment management, a French expert group proposed sediment quality guidelines (N1 and N2) for arsenic and metals in marine sediments (Alzieu and Quiniou, 2001). Below the level N1, the ecological impact is view as negligible. Between $\mathrm{N} 1$ and N2, chemical analyses must be supplemented with toxicity tests. When their contamination level is higher than N2, dredged sediments cannot be discharged into the sea and must be treated or stored on terrestrial environment. In French Mediterranean ports, elevated arsenic concentrations can be found in whole sediments and they often exceed national sediment quality guidelines (Level $1=25 \mathrm{mg} \mathrm{kg}^{-1}$ and Level $2=50 \mathrm{mg} \mathrm{kg}^{-1}$ ) (Mamindy-Pajany et al., 2010b). For example, in the military port of Toulon arsenic level is 4 fold higher than the level 2, suggesting that a significant ecological risk is expected for marine ecosystems and living organisms (Mamindy-Pajany et al., 2010b). The distribution and transport of arsenic in sediment is a complex process, depending on oxidation state, water composition, native bacteria, and sediment type (Guo et al., 1997; Bhattacharya et al., 2007). It has become evident that total concentration alone is not sufficient for a full assessment of arsenic bioavailability and its potential mobility in sediments, thus solid phase speciation studies were developed to characterize arsenic bioavailability in ecosystems and explain its mobility. Published data are focused on the distribution of arsenic within undisturbed sediment and its affinities to the various solid-phase fractions of sediment (Bhattacharya et al., 2006; Baig et al., 2009). Many sequential extractions used for As are based on conventional schemes used to extract metals and other elements that form cations. However, several works highlighted the anionic behaviour of As in sediments, and specific schemes were developed for this metalloid (Gleyzes et al., 2002). In all sequential extraction schemes, arsenic can be extracted in an easily sorbed phase, an $\mathrm{Al}-, \mathrm{Fe}-$ and/or $\mathrm{Mn}$ oxyhydroxide phase and a residual phase. Other operationally defined phases extracted include water or easily soluble, acid volatile sulphide, organic matter, acid-soluble, As oxide and silicate and As sulphide. In oxic and iron-reducing conditions, arsenic species can form strong complexes with iron hydroxides or may be present in oxide minerals. In sulfidic environments, As may adsorb or coprecipitate with pyrite, or form As (III) sulphide minerals (Hudson-Edwards et al., 2004; Wilkin and Ford, 2006).

In the present paper, chemical and toxicity tests were performed to characterize mobility, bioavailability and toxicity of arsenic in marine sediments. Embryo-toxicity and Microtox solid phase tests were selected as bioassays since they provide ecologically relevant information and are rapid and cost-effective screening tools. The oyster (Crassostrea gigas) embryolarval development test is one of the most sensitive and rapid bioassay to check sediment samples considering sub-chronic effects (Geffard et al., 2002; Libralato et al., 2008). Microtox test is an acute toxicity test based on the inhibition of bioluminescence of the marine bacterium Vibrio fischeri (Volpi Ghirardini et al., 2009). Microtox solid phase test 
(MSPT) allows an evaluation of the toxicity of re-suspended sediments; the luminescent bacteria can be in contact with toxicants adsorbed on the particles or dissolved in the water. The geochemical partitioning of As was studied using a sequential extraction procedure specifically developed for appraising arsenic mobility in sediments (Keon et al., 2001). This procedure intends to differentiate the following pools of solid phase arsenic: weakly and strongly adsorbed As; As co-precipitated with metal oxides or amorphous monosulfides; As co-precipitated with crystalline Fe (oxyhydr)oxides; As oxides; As co-precipitated with pyrite and As sulphides (Keon et al., 2001). All experiments were performed with two different Mediterranean marine sediments, one highly polluted with arsenic and other inorganic and organic pollutants (Estaque port (EST)), and the other one, less polluted, with a low arsenic content (Saint Mandrier port (SM)). These sediment samples were well characterized in previous work for mineralogy and physico-chemical composition of solid phases and pore waters (Battaglia-Brunet et al., 2010).

\section{Materials and Methods}

\subsection{Sediment sampling}

Sediment samples were collected on Mediterranean coast in two pleasure ports: Estaque port (EST), highly contaminated with arsenic by several industrial activities and Saint Mandrier port (SM), chosen as a reference site for its low arsenic concentration.

Two different types of samples were collected for each site: surface sediments $(0-10 \mathrm{~cm})$ and depth sediments (10-20 cm). In EST port, two sampling campaigns were performed: one in cold season (March 2009) and another in hot season (September 2009) whereas SM port sediments were considered only in March 2009. The physico-chemical characterization of sediment samples was described in previous work (Battaglia-Brunet et al., 2010). The global risk was estimated in previous work, for each site, using $Q_{P E C}$ (risk quotient) values (Battaglia-Brunet et al., 2010). Results showed that all sediment samples may present a risk for marine environment since their $Q_{P E C}$ values are higher than 1 . The ecological risk is two times higher at EST site, and it is mainly driven by arsenic and three other elements $(\mathrm{Cu}, \mathrm{Pb}$, $\mathrm{Zn}$ ). In $\mathrm{SM}$ sample, the ecological risk is low and is driven by $\mathrm{Cu}$ and $\mathrm{Pb}$ (Battaglia-Brunet et al., 2010). However, this ecological risk parameter does not take into account organic and organo-metallic compounds.

Pollutant concentrations (expressed as $\mathrm{mg} \mathrm{kg}^{-1}$ dry weight) are reported in Table 1 for EST_S1 (Estaque surface, March 2009), EST_S2 (Estaque surface, September 2009), EST_D1 (Estaque depth, March 2009), EST_D2 (Estaque depth, September 2009), SM_S1 (Saint Mandrier surface, March 2009) and SM_D1 (Saint Mandrier depth, March 2009). Arsenic speciation is also reported in Table 1 for all sediment samples and results show that $\mathrm{As}(\mathrm{III})$ is the predominant form in Estaque sediments whereas $\mathrm{As}(\mathrm{V})$ is the major arsenic specie in Saint Mandrier sediments. No methylated arsenic species were detected in samples, indicating that bacterial methylation activity is very low in marine port sediments.

\subsection{Sequential extractions}

Sequential extractions were carried out on Saint Mandrier (SM_S1) and Estaque (EST_S2) surface sediments, following the experimental protocol proposed by Keon et al. (2001). This eight-step procedure was specifically elaborated to sequentially extract As from sediments. A fresh and wet mass of sediment ( $0.4 \mathrm{~g}$ of raw sediment) was mixed with $50 \mathrm{~mL}$ of extracting solutions: successively $\mathrm{MgCl}_{2} 1 \mathrm{M}, \mathrm{NaH}_{2} \mathrm{PO}_{4} 1 \mathrm{M}, \mathrm{HCl} 1 \mathrm{~N}$, ammonium oxalate/oxalic acid 0.2M, Ti(III)-citrate-EDTA-bicarbonate 0.05M, HF $10 \mathrm{M}, \mathrm{HNO}_{3} 16 \mathrm{~N}, \mathrm{HNO}_{3} 16 \mathrm{~N}+30 \% \mathrm{H}_{2} \mathrm{O}_{2}$, 
in order to extract respectively ionically bound As; strongly adsorbed As; As co-precipitated with acid volatile sulphurs, carbonates, Mn oxides and very amorphous Fe oxyhydroxides; As co-precipitated with crystalline Fe oxyhydroxides; As oxides and As co-precipitated with silicates; As co-precipitated with pyrite and amorphous $\mathrm{As}_{2} \mathrm{~S}_{3}$; and orpiment and remaining recalcitrant As minerals. This extraction procedure was realized in triplicate.

After extraction, As total concentration in each supernatant was analysed by ICP-MS (Perkin Elmer Elan DRC II). For each step of the extraction procedure, the calibration solutions were prepared in the same matrix than the sample one. Total As analysis was performed using the external calibration method with an internal standard $(\mathrm{Ge})$. Al, $\mathrm{Ca}, \mathrm{Fe}$ and $\mathrm{Si}$ concentrations were also measured in each extracted fraction using ICP-AES (Perkin Elmer Optima 7300).

\subsection{Toxicity tests on whole sediment}

The sub-chronic test with Crassostrea gigas is based on the observation of embryo-larval development abnormalities. The percentage of abnormalities was determined for a $1: 4$ (sediment:water) ratio at an elutriate concentration corresponding to $250 \mathrm{~g}$ of dried sediment $\mathrm{L}^{-1}$ (Galgani et al., 2009; Mamindy-Pajany et al., 2010a). Reference water was collected offshore Bastia (Corsica, France) and filtered through $0.22 \mu \mathrm{m}$ membrane just before use. Conditioned oyster adults were purchased from the Guernsey Sea Farm Ltd. hatchery (Guernsey, UK) and the test was carried out as described by His et al. (1999). The mature genitors were carefully cleaned and immerged in unfiltered reference water at $18{ }^{\circ} \mathrm{C}$ for 30 min before a thermal shock $\left(28^{\circ} \mathrm{C}, 30 \mathrm{~min}\right)$. Specimens emitting gametes were placed in two successive baths of filtered reference water. Fertilization was monitored under the microscope, then after dilution the larvae were placed in the Iwaki micro-plates (300 larvae per well) and placed in culture at $23 \pm 1^{\circ} \mathrm{C}$ for $24 \mathrm{~h}$. After incubation, larvae were fixed in $40 \%$ formaldehyde and decanted. The abnormality rate is determined on the basis of a count of 100 larvae per well (2-5 replicates per concentration). Test result acceptability was based on controls : (a) negative control as percentage of normal D-shape larvae $\geq 80 \%$ in the reference water (His et al., 1999); (b) positive control as Effective Concentration affecting $50 \%$ of the considered population (EC50) with respect to the reference toxicant $\left(\mathrm{Cu}^{2+}\right.$ as $\left.\mathrm{Cu}\left(\mathrm{NO}_{3}\right)_{2}\right)$ falling within the acceptability range $\left(6-16 \mu \mathrm{g} \mathrm{Cu}^{2+} \mathrm{L}^{-1}\right)$. Abnormalities in controls were under $12 \%$. Results are given as Net Percentage of Abnormalities (NPA) by subtracting the percentage of abnormalities in the negative control from the percentage of abnormalities in sediment elutriates.

The Microtox solid phase test is an acute toxicity test for solid matrix based on the natural bioluminescence inhibition of the marine bacterium Vibrio fischeri. The test was performed using the Azur Environmental standard protocol (Azur Environmental, 1998). A quantity of dried sediment $(10 \mathrm{~g})$ was re-suspended in $100 \mathrm{~mL}$ of diluent solution with magnetic stirring at $1000 \mathrm{rpm}$ for $10 \mathrm{~min}$. Sub-samples from this suspension were used for serial dilutions (1.5 $\mathrm{mL}$, three replicates). Dilutions were equilibrated for $10 \mathrm{~min}$ in a thermostatic bath $a 5^{\circ} \mathrm{C}$. Afterwards, $20 \mu \mathrm{L}$ of revitalized bacteria were added to each tube, gently mixed with a pipette and left in the thermostatic bath to incubate at the same temperature for $20 \mathrm{~min}$. The bacteria were then separated from the sediment by filtration and $500 \mu \mathrm{L}$ subsample of the liquid phase was transferred into the glass cuvettes in the Microtox analyzer and allowed to equilibrate for $15 \mathrm{~min}$ before reading. Light emission was recorded and the output data analyzed using Microtox Omni software Version 1.18 (Mamindy-Pajany et al., 2011). Effective Concentrations provoking $50 \%$ of bioluminescence inhibition (EC50) were determined and converted in toxic unit (TU50 $=100 / E C 50)$ to obtain toxicity data directly correlated to the toxicity magnitude (Mamindy-Pajany et al., 2011). 


\subsection{Toxicity of arsenic species}

As displayed in Table 1, arsenate and arsenite are the main species detected in both sediment samples. The toxicity of these compounds was determined using standard solutions (NIST, National Institute of Standards and Technology) of $10 \mathrm{mg} \mathrm{As}(\mathrm{III})$ or As(V) $\mathrm{L}^{-1}$ in the embryo-toxicity and Microtox liquid phase tests. The toxicity of arsenic species towards oyster larvae was tested in the concentration range $0.1-10 \mathrm{mg} \mathrm{L}^{-1}$ using the same protocol detailed in previous section, and EC50 values (effective concentration provoking $50 \%$ of abnormalities) were calculated using REGTOX software (Vindimian et al., 1983). Microtox liquid phase test was carried out according to the Microtox system operating manual (Azur Environmental, 1998). Five different arsenate and arsenite concentrations were tested in the range $0.1-10 \mathrm{mg} \mathrm{L}^{-1}$ after serial dilution from the standard solution. All tests were performed in three replicates. Light emission was recorded after $30 \mathrm{~min}$ and EC50 values (effective concentration provoking $50 \%$ of bioluminescence inhibition) were calculated using Microtox Omni software Version 1.18.

\subsection{Data analysis}

Statistical analyses were carried out using the software XLSTAT. Data were tested for homogeneity of variance and normal distribution. One-way ANOVAs were used to reveal statistical differences between toxicity data. Post-hoc comparisons between sediment samples were made using the Fisher's test to determine which values significantly differed.

Principal component analysis (PCA) was considered to summarize the relationships between chemical data (Table 1) and bioassays responses (Microtox solid phase and embryo-larval development tests) and account for the variation present in the dataset matrix via biplotting both the ordination component scores and the variable loading coefficients.

\section{Results and discussion}

\subsection{Global toxicity of sediment samples}

The toxicity results on oyster larvae for both sampling periods (March and September) are shown in Fig. 1. Results show that all sediment samples present a significant sub-chronic toxicity to the oyster larvae (between 75 and $100 \%$ of larval anomalies) since the percentage of abnormalities is higher than $50 \%$ in all cases. One-way ANOVA performed on toxicity data is significant $(p=0.0001)$ and significance of post-hoc comparisons is shown in Fig.1. Surface and depth samples are significantly different between sites and sampling periods, except for the first sampling campaign in EST port (EST_S1, EST_D1). In this port, the toxicity level is significantly higher in September than in March. Although sediment contamination is very different for SM and EST, the NPA are not significantly different between SM_S1 and EST depth samples for both sampling periods.

The toxicity levels measured as EC50s in the Microtox solid phase test (MSPT) with the bacterium Vibrio fischeri are shown in Table 2. One-way ANOVA performed on toxicity data is significant $(p=0.0001)$ and significance of post-hoc comparisons is also shown in Table 2. Surface and depth samples are significantly different between the sites and sampling periods, except for the first sampling campaigns in EST (EST_S1, EST_D1) and SM (SM_S1, SM_D1) ports. As observed in the embryo-toxicity test (Fig. 1), the toxicity level in EST sample is significantly higher in September than in March (Table 2). A French regulatory classification was used to calculate toxicity scores in order to discriminate sediment samples as a function of their toxicity level (Table 2). The toxicity scores given for SM are the lowest (with the highest EC50s) whereas they vary from 2 to 3 for EST samples suggesting that toxicity range from medium to high. Contrary to embryo-toxicity test, the MSPT allows 
discriminating the most contaminated sediments (Estaque samples) from the less polluted ones (Saint Mandrier samples). Samples from second sampling period in Estaque site present the highest sub-chronic and acute toxicity levels towards oyster larvae and Vibrio fischeri, respectively. The sub-chronic toxicity measured by the embryo-toxicity test, in decreasing order, is EST_S2 $>$ SM_D1 $\geq$ EST_D2 $\geq$ SM_S1 $\geq$ EST_D1 $\geq$ EST_S1, while the acute toxicity with the MSPT decreases in the following order: EST_D2 $>$ EST_S2 $>$ EST_D1 $\geq$ EST_S1 > SM_S1 $\geq$ SM_D1. The toxicity gradient obtained from the MSPT is in good agreement with $Q_{P E C}$ values. This indicates that the sediment toxicity is strongly related to pollutants strictly linked to the sediment particles, and therefore detectable via the Microtox solid phase test.

In the embryo-toxicity test, the toxicity levels are not correlated to sediment contamination (except for organotins) suggesting that the toxic effect is due to dissolved compounds that has been released from the sediment to elutriates. PCA integrating chemical and toxicity data was performed to establish the relationship between the toxicity and contamination levels in sediment samples (Libralato et al., 2008; Mamindy-Pajany et al., 2011). A biplot summarising PCA results concerning chemical and toxicity data is shown in Fig. 2 . The first two principal components account for 73 and $16 \%$ of the variance, respectively. Thus $89 \%$ of cumulated variance can be depicted by a F1/F2 ordination diagram. The biplot regarding component loadings suggests that the first principal component (F1) is strongly influenced, in increasing order, by $\mathrm{Cu}, \mathrm{Cd}, \mathrm{Zn}, \mathrm{Ni}, \mathrm{Pb}, \mathrm{As}, \mathrm{PCBs}, \mathrm{PAHs}$, mineral oils and TU50 from MSPT which are clustered together and have high positive loadings on the first axis. The second principal component (F2) reflects high values of organotins and NPA. PCA allows discriminating three groups of sediment samples. Along the F1 axis the EST depth group (EST_D1 and EST_D2) characterized by high contaminant concentrations is opposed to the SM group (SM_S1 and SM_D1), with lowest pollutant concentrations. Another group, the EST surface group (EST_S1 and EST_S2), is independent and correlated to the orthogonal axis F2. This group is also strongly correlated with organotins and NPA.

According to the biplot summarising PCA results (Fig. 2), most samples are correlated with Microtox data (TU50 values) and sediment contamination, except the EST surface sediment samples. Arsenic, metals, PCBs, mineral oils and PAHs seem to contribute to toxicity in EST depth samples. According to Fulladosa et al. (2005), the toxicity of dissolved inorganic elements in the Microtox test decreases as follows: $\mathrm{Pb}(\mathrm{II})>\mathrm{Cu}(\mathrm{II})>\mathrm{Zn}(\mathrm{II})>\mathrm{As}(\mathrm{V})>\mathrm{Cd}(\mathrm{II})>$ As(III). It means that arsenic species are not the most toxic compounds in the sediment samples, however they can contribute to sediment toxicity since very high total arsenic concentration can be found in EST samples (Table 1). Surface samples from EST port are correlated with organotins and NPA, suggesting that organotins are the most toxic substances to oyster larvae among measured parameters. Among organotins, TBT is found in significant concentration in surface sediments, and it is well known that this pollutant can strongly affect the embryogenesis and larval development of Crassostrea gigas. Field experiments and laboratory studies have showed that TBT significantly affects embryogenesis from very low concentrations of about $0.05 \mathrm{\mu g} \mathrm{L}^{-1}$ (Alzieu et al., 1986).

\subsection{Toxicity of $\mathrm{As}(\mathrm{III})$ and $\mathrm{As}(\mathrm{V})$}

The embryo-toxicity tests carried out with $\mathrm{As}(\mathrm{III})$ and $\mathrm{As}(\mathrm{V})$ solutions gave EC50 = $1.37 \pm$ $0.13 \mathrm{mg} \mathrm{As}(\mathrm{III}) \mathrm{L}^{-1}$ and $\mathrm{EC} 50=0.92 \pm 0.09 \mathrm{mg} \mathrm{As}(\mathrm{V}) \mathrm{L}^{-1}$. It means that $\mathrm{As}(\mathrm{V})$ is more toxic than $\mathrm{As}(\mathrm{III})$ for oyster larvae. At the highest tested concentration $\left(10 \mathrm{mg} \mathrm{L}^{-1}\right)$, larvae were blocked at the embryo stage (development blocked with visualization of the non-polar lobe corresponding to the entry of spermatozoa) indicating a strong toxicity of arsenic species. Our results are in agreement with literature data, since EC50 values reported in other works vary from 0.33 to $0.92 \mathrm{mg} \mathrm{L}^{-1}$ for As(V) (Martin et al., 1981; PAN, 2007). EC50s obtained with Microtox liquid phase gave a result of $2.20 \pm 0.07 \mathrm{mg} \mathrm{L}^{-1}$ and $0.41 \pm 0.07 \mathrm{mg} \mathrm{L}^{-1}$ for As(III) 
and $A s(V)$, respectively. This result indicates that $A s(V)$ is more toxic than $A s(I I I)$ for Vibrio fisheri. Based on EC20 determination, Fulladosa et al. (2005) have also shown that As(V) is more toxic than As(III) with respect to Vibrio fischeri. The Microtox liquid phase and oyster larvae tests allow discriminating the toxicity of both inorganic arsenic species, confirming that arsenic toxicity is strongly related to its oxidation state. Bacteria are most sensitive to $A s(V)$ than oyster larvae while As(III) is more toxic for the last organism. These results show that arsenic toxicity is also linked to the types of organisms. This can be explained by the toxicity mechanisms, which are different as a function of arsenic species. While As(III) acts by binding to sulfhydryl groups in proteins, As $(\mathrm{V})$ competes with phosphorus to affect oxidative phosphorylation.

According to the previous chemical characterization (Battaglia-Brunet et al., 2010), thioarsenic species were detected in pore water from EST site. The toxicity of thioarsenic species is lower than uncomplexed species (arsenate and arsenite), however, $\mathrm{As}(\mathrm{V})$ remains the most toxic form towards Vibrio fischeri (Rader et al., 2004; Planer-Friedrich et al., 2008).

Few toxicity data are available in number and covering data for marine organisms. In Table 3 , some toxicity data for algae, bacteria, crustaceans, mollusc and fish are compared. Similar toxicities are seen in studies with the marine diatom, Skeletonema costatum, for As(III) and $\mathrm{As}(\mathrm{V})\left(10\right.$ and $13 \mu \mathrm{g} \mathrm{L}^{-1}$, respectively) (Lepper et al., 2007). Arsenate is more toxic than As(III) for all cited organisms except for fish. According toxicity data, neither As(V) nor As(III) is consistently more toxic than the other to aquatic organisms.

\subsection{Arsenic partitioning in sediment samples}

The geochemical partitioning of As in sediments from EST and SM is presented in Table 4. The total concentration of As in Estaque and Saint Mandrier sediments are $99 \pm 19 \mathrm{mg}$ As

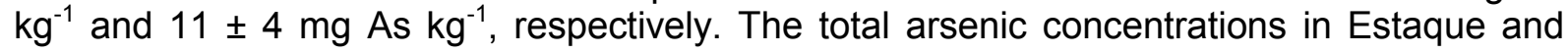
Saint Mandrier sediments obtained by summing As concentrations in fractions 1 to 8 are in good agreement with those presented in Table 1. These last data were obtained by total acid digestion, this suggest that the whole As content was efficiently extracted by the sequential extraction procedure. Arsenic in EST sediment is poorly ionically bound (S1) but strongly adsorbed (S2) and co-precipitated with pyrite as amorphous $\mathrm{As}_{2} \mathrm{~S}_{3}$ (S7), silicates (S6), and orpiment or recalcitrant As mineral (S8) (Table 4). On the other hand, in SM sediment, As is mainly ionically bound (S1) or co-precipitated with silicates (S6) and pyrite as amorphous $\mathrm{As}_{2} \mathrm{~S}_{3}(\mathrm{~S} 7)$ or present as As oxides (S6).

Arsenic adsorbed fraction ( $\mathrm{S} 1$ and S2 fractions) is similar in both sediments (SM and EST), and represents $30 \%$ of the total arsenic concentration (Table 4). In these fractions, major element concentrations ( $\mathrm{Al}, \mathrm{Ca}, \mathrm{Fe}$ and $\mathrm{Si}$ ) are below the detection limit of ICP-AES indicating that only adsorbed arsenic is measured (Table 5). Arsenic is weakly bound in SM (high arsenic concentration in S1) whereas it is mainly specifically adsorbed in EST (highest arsenic mobility in S2). According to Keon et al. (2001), the mobility of arsenic specifically adsorbed (As extracted in S2 fraction) could be due to anionic exchange mechanisms during extraction. Results of the chemical sequential procedure show that arsenic is mainly bounded to solid phase since $70 \%$ of the total arsenic concentration is precipitated or coprecipitated with iron, silicates, or sulphides in both sediment samples (Table 4). Arsenic associated with Fe oxyhydroxides can be estimated by the sum of S3, S4 and S5 fractions, it reaches $13 \%$ and $8 \%$ at SM and EST, respectively. This result is in agreement with iron concentrations detected in these fractions (Table 5). Arsenic inclusion in silicates minerals and co-precipitated with pyrite (in S6 and S7 fractions) represent a significant part of total arsenic concentration (43\% in EST and 54\% in SM). Iron and Si concentrations in S6 and S7 fractions confirm the dissociation of Si-Fe tetrahedron and the oxidation of pyrite crystalline phases from sediment samples, respectively. In addition, high Al and Si concentrations in S6 
fraction demonstrate the dissolution of clay minerals (alumina-silicates detected in sediment samples by Battaglia-Brunet et al., 2010).

In the last extraction step, arsenic concentration is 20 times higher in EST than SM, indicating that arsenic is associated with sulphide minerals such as orpiment. In EST sediment, the formation of $\mathrm{As}_{2} \mathrm{~S}_{3}$ is presumably higher since elevated $\mathrm{As}$ (III) and sulphide activities were detected in previous work (Battaglia-Brunet et al., 2010). In SM sediment, where As concentrations and sulphide activities are very low, sorption to sulphide minerals may be the most important mechanisms for arsenic mobility (Keon et al., 2001). Desorption of arsenic species from sediment components can also occur by the dissolution of iron compounds (due to variation of sediment redox potential) or the competitive interactions of anions (carbonates, chlorides, phosphates, silicates) for sediment adsorption sites. Arsenic species that have become part of a mineral structure or co-precipitated with sulphides from solution have little chance of re-entering the aqueous phase. The distribution coefficient or $\mathrm{Kd}$ values $\left(\mathrm{Kd}=\mathrm{C}_{\text {solid }} / \mathrm{C}_{\text {liquid }}\right)$ can be estimated from sequential extraction data (Kaplan and Serkiz, 2001). Values that are used in the numerator of a $\mathrm{Kd}, \mathrm{C}_{\text {solid, }}$ must not reflect the total amount of contaminant in the sediment, but the reversibly sorbed contaminant concentration. The total reversibly sorbed fraction can be defined by the first 5 extracts (Table 4) and used to calculate $\mathrm{Kd}$ using the following equation: $\mathrm{Kd}=\left(\mathrm{C}_{\text {exchangeable }}+\mathrm{C}_{\mathrm{AmFeOx}}\right) / \mathrm{C}_{\text {porewater }}$

Where $\mathrm{C}_{\text {exchangeable }}$ and $\mathrm{C}_{\mathrm{AmFeOx}}$ are arsenic concentrations in the solid phase extracted in $\mathrm{S} 1$, S2 fractions and S3, S4, S5 fractions, respectively. $C_{\text {porewater }}$ was determined for EST (653 $\mu \mathrm{g}$ $\left.\mathrm{L}^{-1}\right)$ and SM $\left(6 \mu \mathrm{g} \mathrm{L}^{-1}\right)$ in Battaglia-Brunet et al. (2010). The 5 extracts used to define $\mathrm{C}_{\text {solid }}$ are not expected to recover arsenic occulted in silicates, aluminosilicates, arsenic co-precipitated with pyrite and crystalline, amorphous As sulphides phase (Table 4).

The Kd value is greater in SM $\left(450 \mathrm{~L} \mathrm{~kg}^{-1}\right)$ than in EST $\left(55 \mathrm{~L} \mathrm{~kg}^{-1}\right)$, and there is one order of magnitude between these values. Thus, arsenic mobility is 9 times higher in the most contaminated sediment i.e. EST sediment. The predominance of As(III) at EST and As(V) at SM can explain this discrepancy between Kd values. Indeed, As(III) is a neutral, uncharged molecule $\left(\mathrm{H}_{3} \mathrm{AsO}_{3}{ }^{0}\right.$, pKa $\left.=9.2\right)$ at the $\mathrm{pH}$ of most natural waters and is more mobile than the negatively charged $\mathrm{As}(\mathrm{V})$ oxyanions. Published data have shown the highest affinity of arsenate over arsenite to sediment components such as aluminium and iron oxides, and aluminosilicates (Goldberg, 2002). Furthermore, Bang and Meng (2004) have shown that silicates, phosphates and bicarbonates in individual solutions decrease As(III) adsorption at relatively low concentrations and surface site coverage but they have no effects or moderate effects on $\mathrm{As}(\mathrm{V})$ adsorption.

Toxicity data (EC50 values obtained from the MSPT for arsenic species) and the Kd value obtained for Estaque sediment can be used to estimate the total arsenic concentration provoking toxic effects to Vibrio fischeri. It emerges that $\mathrm{As}(\mathrm{V})$ and $\mathrm{As}(\mathrm{III})$ inhibit $50 \%$ of the bioluminescence of $\mathrm{V}$. fischeri from $22 \mathrm{mg} \mathrm{kg}^{-1}$ and $121 \mathrm{mg} \mathrm{kg}^{-1}$, respectively. According to Table 1 , arsenic concentrations in the whole sediments are higher than these values, confirming that As-contaminated sediments are able to provoke significant toxic effects on $\mathrm{V}$. fischeri. To evaluate the potential ecotoxicological effects associated with the observed concentrations of contaminants in the whole sediment samples, different published sediment quality guidelines (SQGs) can be used (Apitz et al., 2007). Among the main approaches used to establish SQGs, the equilibrium partitioning model has been developed theoretically to account for the factors that likely influence metal bioavailability in bed anaerobic sediments (Babut et al., 2003). The other approach, the co-occurence method, developed SQGs empirically using different statistical methods on the basis of the observed associations between large data sets of measured adverse biological effects and the concentration of potentially toxic substances present in marine sediment (Alzieu and Quiniou, 2001). According to the literature, arsenic concentrations (corresponding to the no observed effect 
concentration) derived from equilibrium partitioning and co-occurence methods are equal to 29 (Babut et al., 2003) and $25 \mathrm{mg} \mathrm{kg}^{-1}$ (Alzieu and Quiniou, 2001), respectively. It means that arsenic can provoke toxic effects above these concentration levels. In the present study, arsenic concentrations derived from the Microtox toxicity test and the chemical sequential procedure are not the same for $\mathrm{As}(\mathrm{V})$ and $\mathrm{As}(\mathrm{III})$. Indeed, $\mathrm{As}(\mathrm{V})$ level $\left(22 \mathrm{mg} \mathrm{kg}^{-1}\right)$ is close to the no observed effect concentrations $\left(25-29 \mathrm{mg} \mathrm{kg}^{-1}\right)$ while As(III) concentration (122 $\mathrm{mg} \mathrm{kg}^{-}$ ${ }^{1}$ ) is 4 times higher than the guideline values. It means that sediment quality guidelines underestimate the toxicity of $\mathrm{As}(\mathrm{V})$ towards Vibrio fischeri since significant toxic effects $(50 \%$ inhibition of bioluminescence) can be detected from $22 \mathrm{mg} \mathrm{As}(\mathrm{V})$ per $\mathrm{kg}$ of dry sediment. This finding indicates that arsenic speciation should be taken into account to derive more relevant sediment quality guidelines for arsenic.

\section{Conclusions}

This paper describes arsenic mobility and its bioavailability in two different Mediterranean marine sediments, one highly polluted with arsenic (Estaque port (EST)), and the other one with a low arsenic content (Saint Mandrier port (SM)). Ecotoxicological evaluation with laboratory toxicity tests showed that sub-chronic and acute toxic effects were detected for all sediment samples. In the Microtox solid phase test, EST samples induced higher toxic effects than SM ones. The toxicity gradient was not the same with the embryo-toxicity test, and the toxicity level of SM samples were not always significantly different to EST ones. From these results it was evident that arsenic species were the most toxic compounds in sediment samples but the high level of arsenic in the solid phase could contribute to the global toxicity of As-contaminated samples (EST samples). The chemical sequential procedure was used to study arsenic mobility in surface sediment samples, and results showed that the exchangeable fraction (ionically and specifically adsorbed) represented $30 \%$ of the total arsenic concentration in both sediments. It meant that $70 \%$ of the total arsenic concentration was precipitated or co-precipitated with iron, silicates, or sulphides in both sediment samples. Estimation of Kd values from the chemical sequential procedure indicated that arsenic mobility was 9 times higher in the most contaminated sample (EST sediment) than in SM. Arsenic mobility in EST sediment was explained by the predominance of As(III) in the whole sediment and the low affinity of this compound to sediment adsorption sites. The toxicity level of arsenic species in the whole sediment was determined and results showed that arsenic sediment quality criteria underestimated the toxicity of $\mathrm{As}(\mathrm{V})$ towards Vibrio fischeri. The toxicity of As-contaminated sediments is strongly linked to arsenic speciation in the whole sediment indicating that regulatory levels should be determined for the main arsenic species in marine sediment i.e. As(III) and As(V).

\section{Acknowledgements}

This study was part of ASEDMAR project, supported by the French National Research Agency, under reference 2008 CESA-003".

\section{References}

Alzieu, C.L., Sanjuan, J., Deltreil, J.P., Borel, M., 1986. Tin contamination in Arcachon Bay: Effects on oyster shell anomalies. Mar. Pollut. Bull. 17, 494-498.

Alzieu, C., Quiniou, F., 2001. Software to assess risks related to dumping of dredged sediments from maritime harbours. Geodrisk, in CD-ROM Geodrisk. 
Andral, B., Stanisiere, J.Y., Sauzade, D., Damier, E., Thebault, H., Galgani, F., Boissery, P., 2004. Monitoring chemical contamination levels in the Mediterranean based on the use of mussel caging. Mar. Pollut. Bull. 49, 704-712.

Apitz, S., Barbanti, A., Giulio Bernstein, A., Bocci, M., Delaney, E., Montobbio, L., 2007. The assessment of sediment screening risk in Venice Lagoon and other coastal areas using international sediment quality guidelines. J. Soils Sediments 7, 326-341.

Azur Environmental, 1998. Microtox Acute Toxicity Test Guide, Users Manual.

Babut, M., Garric, J., Camusso, M., den Besten, P.J., 2003. Use of sediment quality guidelines in ecological risk assessment of dredged materials: preliminary reflections. Aquat. Ecosys. Health. Manag. 6, 359-367.

Baig, J.A., Kazi, T.G., Arain, M.B., Shah, A.Q., Sarfraz, R.A., Afridi, H.I., Kandhro, G.A., Jamali, M.K., Khan, S., 2009. Arsenic fractionation in sediments of different origins using BCR sequential and single extraction methods. J. Hazard. Mater. 167, 745-751.

Bang, S.B., Meng, X.G., 2004. A Review of Arsenic Interactions with Anions and Iron Hydroxides. Environ. Eng. Res. 9, 184-192.

Battaglia-Brunet, F., Joulian, C., Guezennec, A.-G., Bataillard, P., Marmier, N., Hurel, C., Barats, A., Philippini, V., Mamindy-Pajany, Y., Roméo, M., Bertin, P., Koechler, S., Séby, F., Moulin, A., 2010. Arsenic in marine sediments: Modeling the link between Biogeochemistry, Bioavailability and Ecotoxicology. Third International Congress on "Arsenic in the Environment", Taiwan.

Bhattacharya, P., Claesson, M., Bundschuh, J., Sracek, O., Fagerberg, J., Jacks, G., Martin, R.A., Storniolo, A.d.R., Thir, J.M., 2006. Distribution and mobility of arsenic in the Río Dulce alluvial aquifers in Santiago del Estero Province, Argentina. Sci. Total Environ. 358, 97-120.

Bhattacharya, P., Welch, A.H., Stollenwerk, K.G., McLaughlin, M.J., Bundschuh, J., Panaullah, G., 2007. Arsenic in the environment: Biology and Chemistry. Sci. Total Environ. 379, 109-120.

Eggleton, J., Thomas, K.V., 2004. A review of factors affecting the release and bioavailability of contaminants during sediment disturbance events. Environ. Int. 30, 973-980.

Fulladosa, E., Murat, J.C., Martínez, M., Villaescusa, I., 2005. Patterns of metals and arsenic poisoning in Vibrio fischeri bacteria. Chemosphere 60, 43-48.

Galgani, F., Senia, J., Guillou, J., Laugier, T., Munaron, D., Andral, B., Guillaume, B., Coulet, E., Boissery, P., Brun, L., Bertrandy, M., 2009. Assessment of the Environmental Quality of French Continental Mediterranean Lagoons with Oyster Embryo Bioassay. Arch. Environ. Con. Tox. 57, 540-551.

Geffard, O., Budzinski, H., His, E., Seaman, M.N.L., Garrigues, P., 2002. Relationships between between contaminant levels in marine sediments and their biological effects on embryos of oyster, Crassostrea Gigas. Environ. Toxicol. Chem. 21, 2310-2318.

Gleyzes, C., Tellier, S., Astruc, M., 2002. Fractionation studies of trace elements in contaminated soils and sediments: a review of sequential extraction procedures. TrACTrend. Anal. Chem. 21, 451-467. 
Goldberg, S., 2002. Competitive Adsorption of Arsenate and Arsenite on Oxides and Clay Minerals. Soil Sci. Soc. Am. J. 66, 413-421.

Guo, T., DeLaune, R.D., Patrick Jr, W.H., 1997. The influence of sediment redox chemistry on chemically active forms of arsenic, cadmium, chromium, and zinc in estuarine sediment. Environ. Int. 23, 305-316.

His, E., Beiras, R., Seaman, M.N.L., 1999. The assessment of marine pollution-bioassays with bivalve embryos and larvae. Adv. Mar. Biol. 37, 1-178.

Hudson-Edwards, K.A., Houghton, S.L., Osborn, A., 2004. Extraction and analysis of arsenic in soils and sediments. TrAC-Trend. Anal. Chem. 23, 745-752.

Kaplan, D., Serkiz, S., 2001. Quantification of thorium and uranium sorption to contaminated sediments. J. Radioanal. Nucl. Chem. 248, 529-535.

Keon, N.E., Swartz, C.H., Brabander, D.J., Harvey, C., Hemond, H.F., 2001. Validation of an Arsenic Sequential Extraction Method for Evaluating Mobility in Sediments. Environ. Sci. Technol. 35, 2778-2784.

Lepper, P., Sorokin, N., Maycock, D., Crane, M., Atkinson, C., Hope, S., Comber, S., 2007. Proposed EQS for Water Framework Directive Annex VIII substances: arsenic (total dissolved). Environment Agency, Bristol (UK), pp. 25-30.

Libralato, G., Losso, C., Arizzi Novelli, A., Citron, M., Della Sala, S., Zanotto, E., Cepak, F., Volpi Ghirardini, A., 2008. Ecotoxicological evaluation of industrial port of Venice (Italy) sediment samples after a decontamination treatment. Environ. Pollut. 156, 644-650.

Mamindy-Pajany, Y., Galgani, F., Roméo, M., Hurel, C., Marmier, N., 2010a. Minerals as additives for decreasing the toxicity of Mediterranean contaminated dredged sediments. Ecotox. Environ. Safe. 73, 1748-1754.

Mamindy-Pajany, Y., Hamer, B., Roméo, M., Géret, F., Galgani, F., Durmisi, E., Hurel, C., Marmier, N., 2011. The toxicity of composted sediments from Mediterranean ports evaluated by several bioassays. Chemosphere $82,362-369$.

Mamindy-Pajany, Y., Libralato, G., Roméo, M., Hurel, C., Losso, C., Ghirardini, A.V., Marmier, N., 2010b. Ecotoxicological evaluation of Mediterranean dredged sediment ports based on elutriates with oyster embryotoxicity tests after composting process. Water Res. 44, 1986-1994.

Martin, M., Osborn, K.E., Billig, P., Glickstein, N., 1981. Toxicities of ten metals to Crassostrea gigas and Mytilus edulis embryos and Cancer magister larvae. Mar. Pollut. Bull. $12,305-308$

PAN, 2007. PAN Pesticides Database - Chemical Toxicity Studies on Aquatic Organisms. http://www.pesticideinfo.org.

Planer-Friedrich, B., Franke, D., Merkel, B., Wallschläger, D., 2008. Acute toxicity of thioarsenates to Vibrio fischeri. Environ. Toxicol. Chem. 27, 2027-2035.

Rader, K.J., Dombrowski, P.M., Farley, K.J., Mahony, J.D., Di Toro, D.M., 2004. Effect of thioarsenite formation on arsenic(III) toxicity. Environ. Toxicol. Chem. 23, 1649-1654. 
Vindimian, E., Robaut, C., Fillion, G., 1983. A method for co-operative and non co-operative 650 binding studies using non-linear regression analysis on a microcomputer J. Appl. Biochem. 5, 261- 268.

Volpi Ghirardini, A., Girardini, M., Marchetto, D., Pantani, C., 2009. Microtox solid phase test: Effect of diluent used in toxicity test. Ecotox. Environ. Safe. 72, 851-861.

Wilkin, R.T., Ford, R.G., 2006. Arsenic solid-phase partitioning in reducing sediments of a contaminated wetland. Chem. Geol. 228, 156-174. 


\section{Tables}

Table 1. Chemical concentrations (expressed as $\mathrm{mg} \mathrm{kg}^{-1}$ dry weight) in sediment samples from Saint Mandrier and Estaque (surface and depth) collected in March and September 2009. As comparison French sediment quality guidelines (N1 and N2 levels) are also reported (Alzieu and Quiniou, 2001).

\begin{tabular}{|c|c|c|c|c|c|c|c|c|c|}
\hline Pollutants & Units & EST_S1 & EST_D1 & EST_S2 & EST_D2 & SM_S1 & SM_D1 & N1 & N2 \\
\hline $\mathrm{As}(\mathrm{III})$ & $\mathrm{mg} \mathrm{kg}^{-1}$ & 148 & 170 & 73 & 186 & 1.4 & 4 & - & - \\
\hline $\mathrm{As}(\mathrm{V})$ & $\mathrm{mg} \mathrm{kg}^{-1}$ & 46 & 29 & 34 & 34 & 8.6 & 8.1 & - & - \\
\hline Total As & $\mathrm{mg} \mathrm{kg}^{-1}$ & 194 & 199 & 107 & 220 & 10 & 12.1 & 25 & 50 \\
\hline $\mathrm{Cd}$ & $\mathrm{mg} \mathrm{kg}^{-1}$ & 0.3 & 0.4 & - & - & - & - & 1.2 & 2.4 \\
\hline $\mathrm{Cu}$ & $\mathrm{mg} \mathrm{kg}^{-1}$ & 278 & 273 & - & - & 220 & 194 & 45 & 90 \\
\hline $\mathrm{Ni}$ & $\mathrm{mg} \mathrm{kg}^{-1}$ & 20 & 24 & - & - & 15 & 19 & 37 & 74 \\
\hline $\mathrm{Pb}$ & $\mathrm{mg} \mathrm{kg}^{-1}$ & 329 & 412 & - & - & 110 & 108 & 100 & 200 \\
\hline $\mathrm{Zn}$ & $\mathrm{mg} \mathrm{kg}^{-1}$ & 375 & 463 & 538 & 631 & 221 & 209 & 276 & 552 \\
\hline Mineral oils & $\mathrm{mg} \mathrm{kg}^{-1}$ & 1,141 & 1,646 & - & - & 588 & 250 & - & - \\
\hline$\sum \mathrm{PAHs}$ & $\mathrm{mg} \mathrm{kg}^{-1}$ & 2.3 & 5.9 & - & - & 1.2 & 0.3 & - & - \\
\hline$\sum \mathrm{PCBS}$ & $\mathrm{mg} \mathrm{kg}^{-1}$ & 0.12 & 0.16 & - & - & 0.10 & 0.10 & - & - \\
\hline TBT & $\mu g \mathrm{Sn} \mathrm{kg}^{-1}$ & 374 & 59 & - & - & 179 & 43 & 400 & 1,000 \\
\hline DBT & $\mu g$ Sn $\mathrm{kg}^{-1}$ & 224 & 63 & - & - & 142 & 32 & - & - \\
\hline MBT & $\mu g$ Sn $\mathrm{kg}^{-1}$ & 347 & 39 & - & - & 197 & 37 & - & - \\
\hline
\end{tabular}


Table 2. EC50 and TU50 (100/EC50) values provoking 50\% inhibition of bioluminescence of Vibrio fischeri after 15 min in the Microtox solid phase test. EC50 values were used to calculate toxicity score according French regulation for management of marine dredged sediment (Alzieu and Quiniou, 2001). Means $(n=3) \pm 1$ SD; different letters differed significantly (Fischer's test at $p<0.007)$ after significant global ANOVA ( $p=$ $0.0001)$

\begin{tabular}{cccc}
\hline Sediment samples & EC50 $\left(\mathrm{g} \mathrm{L}^{-1}\right)$ & Toxicity score & TU50 \\
\hline EST_S1 & $0.29 \pm 0.04$ & 2 & $344 \pm 48^{\mathrm{c}}$ \\
EST_D1 & $0.27 \pm 0.02$ & 2 & $370 \pm 28^{\mathrm{c}}$ \\
\hline EST_S2 & $0.15 \pm 0.01$ & 3 & $666 \pm 44^{\mathrm{b}}$ \\
\hline EST_D2 & $0.13 \pm 0.01$ & 3 & $769 \pm 59^{\mathrm{a}}$ \\
\hline SM_S1 & $0.71 \pm 0.11$ & 1 & $141 \pm 22^{\mathrm{d}}$ \\
\hline SM_D1 & $0.96 \pm 0.11$ & 1 & $104 \pm 12^{\mathrm{d}}$ \\
\hline
\end{tabular}


Table 3. Long term and acute toxicity of arsenic species for some saltwater species

\begin{tabular}{|c|c|c|c|c|c|c|c|}
\hline $\begin{array}{l}\text { Taxonomic } \\
\text { group }\end{array}$ & Species & $\begin{array}{c}\text { Common } \\
\text { name }\end{array}$ & $\begin{array}{c}\text { Toxicity } \\
\text { endpoints }\end{array}$ & Effect & $\mathrm{As}(\mathrm{III})$ & $\mathrm{As}(\mathrm{V})$ & Reference \\
\hline & & \multicolumn{6}{|c|}{ Long term toxicity } \\
\hline Algae & Skeletonema costatum & Diatom & LOEC & Growth & 0.010 & 0.013 & Lepper et al., 2007 \\
\hline Crustaceans & Americamysis bahia & Opossum shrimp & NOEC & Reproduction & 0.631 & - & Lepper et al., 2007 \\
\hline Crustaceans & Palaemonetes pugio & Daggerblade grass shrimp & NOEC & Growth & - & 0.025 & Lepper et al., 2007 \\
\hline \multirow[t]{2}{*}{ Mollusk } & Crassostrea gigas & Oyster larvae & EC50 & Larval development & 1.370 & 0.920 & This study \\
\hline & & \multicolumn{6}{|c|}{ Short term toxicity } \\
\hline Bacteria & Vibrio fisheri & Bacteria & EC50 & Inhibition bioluminescence & 2.200 & 0.410 & This study \\
\hline Crustaceans & Acartia clausi & Calanoid copepod & LC50 & Mortality & 0.907 & - & Lepper et al., 2007 \\
\hline Crustaceans & Tigriopus brevicornis & Harpacticoid copepod & LC50 & Mortality & - & 0.011 & Lepper et al., 2007 \\
\hline Fish & Therapon jarbua & Tigerfish & LC50 & Mortality & 3.380 & - & Lepper et al., 2007 \\
\hline Fish & Morone saxatilis & Striped bass & LC50 & Mortality & - & 10.30 & Lepper et al., 2007 \\
\hline
\end{tabular}

EC50: Effective concentration inducing $50 \%$ of effect

LC50: Lethal concentration inducing $50 \%$ of effect

LOEC: Lowest Observed Effect Concentration

NOEC: No Observed Effect Concentration 
Table 4. The concentrations and relative percentages of arsenic in the different sediment fractions ( 1 to S8) extracted from surface sediment samples (Estaque: EST, Saint Mandrier: SM) using the chemical sequential procedure.

\begin{tabular}{ccccc}
\hline & \multicolumn{3}{c}{ EST } & \multicolumn{2}{c}{ SM } \\
\cline { 2 - 5 } Fractions & As $\left(\mathrm{mg} \mathrm{kg}^{-1}\right)$ & As (\%) & As $\left(\mathrm{mg} \mathrm{kg}^{-1}\right)$ & As (\%) \\
\hline S1 & 0.44 & 0.4 & 2.92 & 27 \\
S2 & 28.95 & 29.4 & 0.55 & 5 \\
S3 & 6.01 & 6.1 & 0.05 & 0.4 \\
S4 & 0.51 & 0.5 & 0.07 & 0.7 \\
S5 & 0.96 & 1.0 & 1.26 & 11.6 \\
S6 & 16.25 & 16.5 & 3.14 & 29 \\
S7 & 25.58 & 26 & 2.68 & 24.7 \\
S8 & 19.82 & 20.1 & 0.17 & 1.6 \\
\hline$\Sigma$ fractions & 98.51 & 100 & 10.83 & 100 \\
\hline
\end{tabular}


Table 5. Al, Ca, Fe and Si concentrations in the different sediment fractions (S1 to S8) extracted from surface sediment samples (Estaque: EST, Saint Mandrier: SM) using the chemical sequential procedure

\begin{tabular}{ccccccccc}
\hline & \multicolumn{2}{c}{$\mathrm{Al}\left(\mathrm{mg} \mathrm{kg}^{-1}\right)$} & \multicolumn{2}{c}{$\mathrm{Ca}\left(\mathrm{mg} \mathrm{kg}^{-1}\right)$} & \multicolumn{2}{c}{$\mathrm{Fe}\left(\mathrm{mg} \mathrm{kg}^{-1}\right)$} & \multicolumn{2}{c}{$\mathrm{Si}\left(\mathrm{mg} \mathrm{kg}^{-1}\right)$} \\
\cline { 2 - 9 } Fractions & EST & SM & EST & SM & EST & SM & EST & SM \\
\hline S1 & - & - & - & - & - & - & - & - \\
S2 & - & - & - & - & - & - & - & - \\
S3 & 1,170 & 820 & 107,000 & 64,000 & 6,440 & 3,140 & 940 & 620 \\
S4 & 100 & 130 & 10 & 10 & 310 & 580 & 20 & 40 \\
S5 & 340 & 550 & 390 & 270 & 670 & 1,370 & 80 & 260 \\
S6 & 16,800 & 41,800 & 400 & 530 & 4,430 & 6,660 & 109,000 & 267,000 \\
S7 & 20 & 20 & - & 2 & 4,660 & 1,240 & 13,000 & 6,200 \\
S8 & 10 & 20 & - & 3 & - & 4 & 1,100 & 260 \\
\hline
\end{tabular}




\section{Figures}

Figure 1. Net percentage of abnormalities (NPA) of oyster larvae in sediment elutriates at $250 \mathrm{~g} \mathrm{~L}^{-1}$. Mean value $(n=3) \pm 1 \mathrm{SD}$; different letters differed significantly (Fischer's test at $p$ $<0.03$ ) after significant global ANOVA ( $p=0.0001)$.

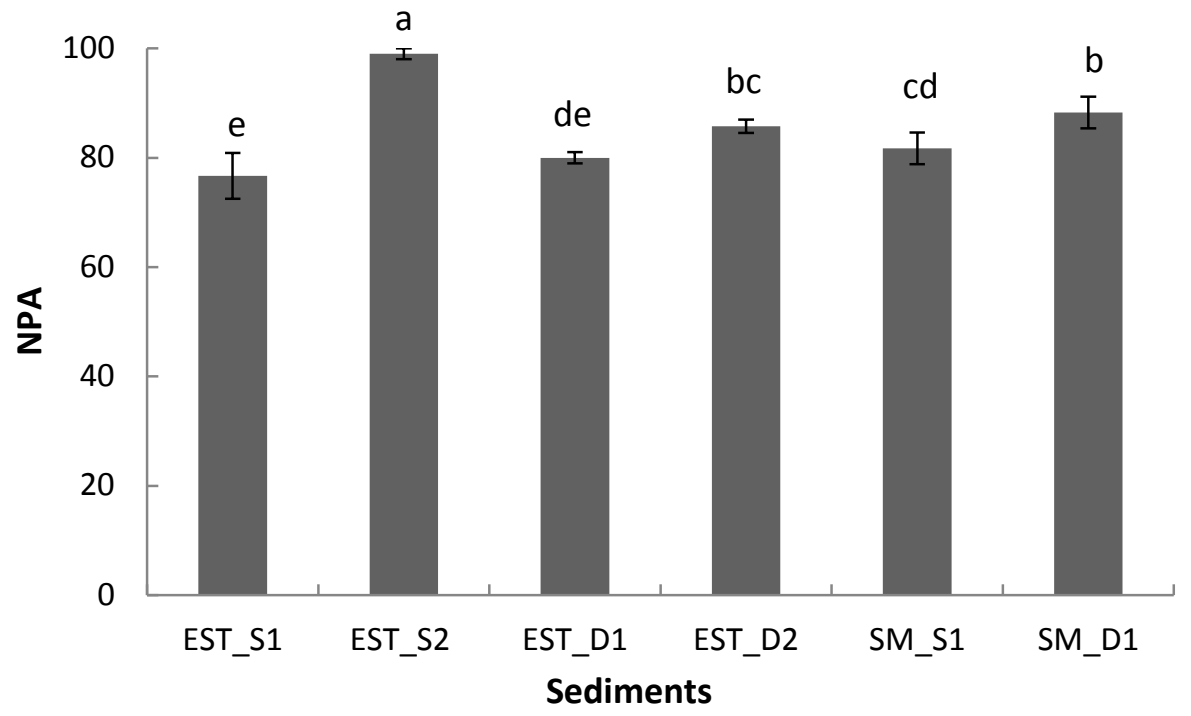

Figure 2. Principal component analysis biplot of chemical data and toxicity results with loadings and scores in the coordinates of the first two principal components (F1 and F2).

Biplot ( F1 and F2 axis : 89\%)

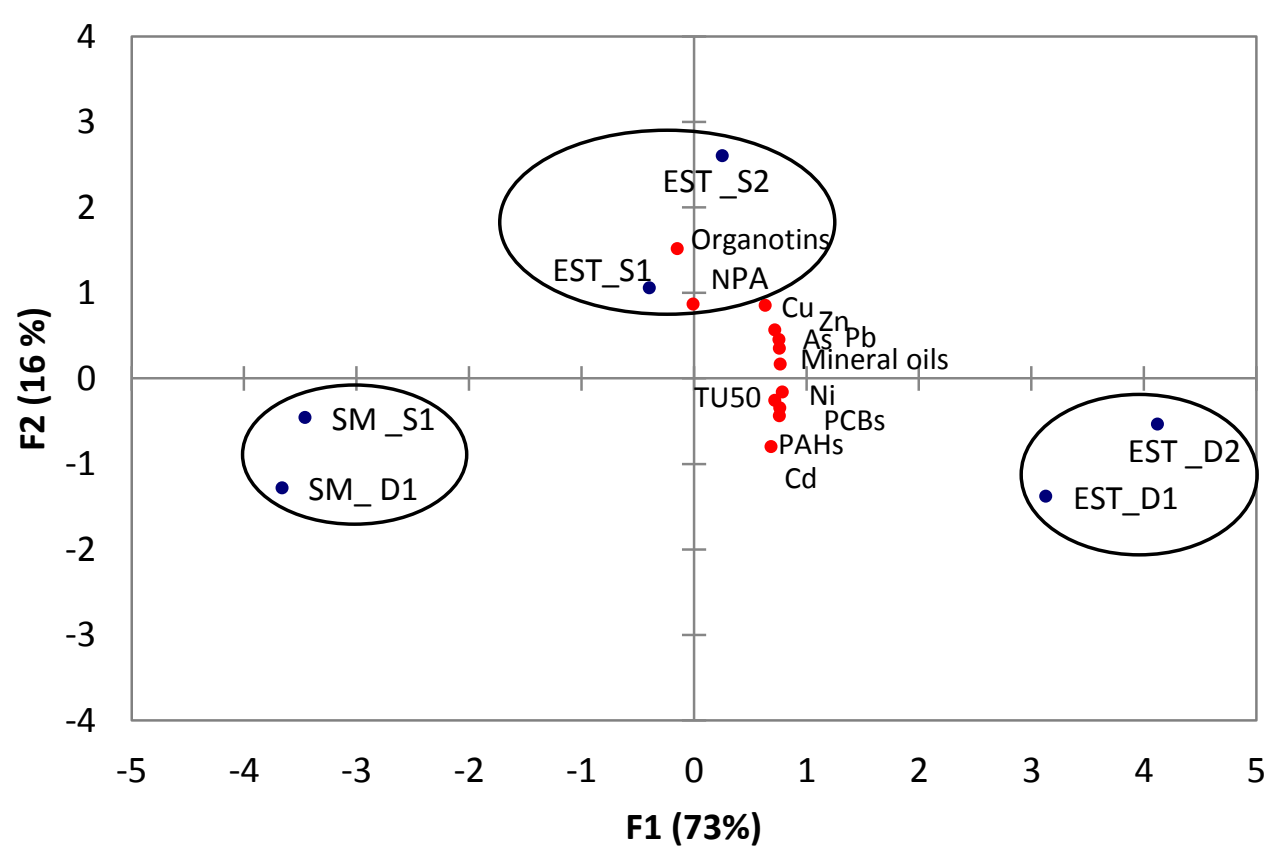

